Florida NAtUral AREAS INVENTORY. 1990. Guide to the Natural Communities of Florida. Florida Natural Areas Inventory and Florida Dept. of Natural Resources, Tallahassee, Florida.

FRANZ, R. 1986. The Florida gopher frog and Florida pine snake as burrow associates of the gopher tortoise in northern Florida. In D. R. Jackson and R. J. Bryant (eds.), Proc. Fifth Ann. Mtg. Gopher Tortoise Council, pp. 16-20. Florida State Museum, Gainesville.

GENTRY, J. B., AND M. H. SMITH. 1968. Food habits and burrow associates of Peromyscus polionotus. J. Mammal. 49:562-565.

GerhardT, H. C., R. E. DANiel, S. A. Perrill, AND S. SCHRAMM. 1987. Mating behaviour and male mating success in the green treefrog. Anim. Behav. 35: 1490-1503.

GibBons, J. W., AND D. H. BennetT. 1974. Determination of anuran terrestrial activity patterns by a drift fence method. Copeia 1974:236-243.

GoDLEY, J. S. 1992. Threatened: Gopher frog Rana capito Le Conte. In P. E. Moler (ed.), Rare and Endangered Biota of Florida, Volume 3. Amphibians and Reptiles, pp. 15-19. Univ. Press of Florida, Gainesville.

GodwIN, G. J., AND S. M. RoBLE. 1983. Mating success in male treefrogs, Hyla chrysoscelis (Anura: Hylidae). Herpetologica 39:141-146.

HowARD, R. D. 1978. The evolution of mating strategies in bullfrogs, Rana catesbeiana. Evolution 32: 850-871.

- 1980. Mating behaviour and mating success in wood frogs, Rana sylvatica. Anim. Behav. 28:705716.
LEE, D. S. 1968 . Herpetofauna associated with central Florida mammals. Herpetologica 24:83-84.

Martof, B. S., W. M. PAlmer, J. R. BAILEY, AND J. R. HARRISON. 1980. Amphibians and Reptiles of the Carolinas and Virginia. Univ. of North Carolina Press, Chapel Hill.

MEANS, D. B. 1986. Threatened: Dusky gopher frog. In R. H. Mount (ed.), Vertebrate Animals in Need of Special Attention in Alabama, pp. 30-31. Alabama Agric. Exp. Sta., Auburn, Alabama.

MounT, R. H. 1975. The Reptiles and Amphibians of Alabama. Auburn Univ. Agricultural Exp. Sta., Auburn, Alabama.

Semlitsch, R. D., J. W. GibBOns, AND T. D. Tuberville. 1995. Timing of reproduction and metamorphosis in the Carolina gopher frog (Rana capito capito) in South Carolina. J. Herpetol. 29:612-614.

SHOOP, C. R., AND T. L. DOTY. 1972. Migratory orientation by marbled salamanders (Ambystoma opacum) near a breeding area. Behav. Biol. 7:131-136.

VOLPE, E. P. 1958. The early development of Rana capito sevosa. Tulane Stud. Zool. 5:207-225.

WeLLS, K. D. 1977. Territoriality and male mating success in the green frog (Rana clamitans). Ecology 58:750-762.

WOODWARD, B. D. 1982. Male persistence and mating success in Woodhouse's toad (Bufo woodhousei). Ecology 63:583-585.

WRIGHT, A. H. 1931. Life Histories of the Frogs of the Okefinokee Swamp, Georgia. MacMillan Co, New York.

Accepted: 16 January 1998.

\title{
A New Species of Rana from the Terai of Nepal
}

\author{
INDRANEIL DAS ${ }^{1}$ \\ Museum of Comparative Zoology, Harzard University, Cambridge, Massachusetts 02138, USA
}

Abstract.-A new species of Rana is described from the terai region of Nepal on the basis of three specimens. The new species is diagnosable from known congeners in possessing the following characteristics: head longer than wide; tympanum rounded, smaller than orbit diameter; supratympanic fold absent; finger I longer than finger II; a series of large, flat glands on lateral aspect of body; broad webbing on toe IV to penultimate subarticular tubercle, reaching tip of toes as a narrow sheath; tips of digits flattened to form disks with distinct circummarginal grooves separating dorsum of disks from ventrum; tibia length/ snout-vent length ratio 47.23-54.15; and absence of humeral gland on forelimb of males. The snout-vent length range shown by the type series is $30.4-32.5 \mathrm{~mm}$.

The Terai region of Nepal, at the foothills of the Himalayan range, comprises extensive

\footnotetext{
${ }^{1}$ Present Address: Centre for Herpetology, Madras Crocodile Bank Trust, Post Bag 4, Mamallapuram, Tamil Nadu 603 104, India.
}

marshes and associated grasslands, formed by the seepage of the larger streams (Mani, 1974a). Once $80-100 \mathrm{~km}$ in width, the Terai, which is dominated by tall grass and Tamarix, with patches of Shorea forest, has been reduced to a relatively narrow belt through anthropogenic 
TABLE 1. Measurements (in $\mathrm{mm}$ ) on the type series of Rana chitwanensis sp. nov. (see text for details).

\begin{tabular}{lrrr}
\hline \hline & USNM & USNM & USNM \\
& 266837 & 266838 & 266839 \\
\hline Snout-vent length & 32.5 & 30.7 & 30.4 \\
Trunk length & 11.5 & 12.7 & 13.4 \\
Head length & 11.1 & 10.3 & 10.1 \\
Head width & 10.0 & 9.1 & 4.4 \\
Head depth & 5.7 & 6.2 & 5.5 \\
Eye diameter & 4.2 & 4.0 & 3.7 \\
Interorbital diameter & 6.1 & 5.3 & 4.9 \\
Internarial distance & 3.5 & 3.0 & 3.2 \\
Eye-snout-tip distance & 5.4 & 4.4 & 4.7 \\
Eye-nostril distance & 3.2 & 2.6 & 2.8 \\
Eye-tympanum distance & 1.3 & 0.7 & 1.2 \\
Tibia length & 17.6 & 14.5 & 14.9 \\
Disk diameter finger II & 0.6 & 0.6 & 0.6 \\
Horizontal tympanum diameter & 2.9 & 2.3 & 2.2 \\
Vertical tympanum diameter & 2.7 & 2.2 & 2.3 \\
\hline
\end{tabular}

pressures (Mani, 1974b). Within the various forest types represented in Nepal, the Terai supports the highest amphibian species diversity (Swan and Leviton, 1962; Dubois, 1973, 1974, 1975, 1976; Dubois and Matsui, 1983).

A new species of Rana is here described from the Terai of Nepal, based on three examples that have been reported earlier as Rana danieli Pillai and Chanda (1977) by Zug and Mitchell (1995) and Mitchell and Zug (1995). Schleich et al. (1993) have also included the species is their checklist, and Maskey and Schleich (1992) listed a species as " $R$. cf. danieli."

\section{MATERIALS AND MethodS}

Measurements were taken with a Mitutoyo dial vernier calliper (to the nearest $0.1 \mathrm{~mm}$ ) from specimens preserved in $70 \%$ ethanol. The following measurements were taken: snout-vent length, SVL (from tip of snout to vent); tibia length, TBL (distance between surface of knee to surface of heel, with both tibia and tarsus flexed); trunk length, TL (distance between posterior edge of forelimb at its insertion to body to anterior edge of hind limb at its insertion to body); head length, HL (distance between angle of jaws and snout-tip); head width, HW (measured at angle of jaws); head depth, HD (greatest transverse depth of head, taken beyond orbital region); eye diameter, ED (diameter of orbit); eye to tympanum distance, E-T (distance between posterior-most point of eyes and anterior-most point of tympanum); interorbital width, IO (least distance between upper eyelids); internarial distance, IN (distance between nostrils); eye to snout-tip distance, E-S (distance between anterior-most point of eyes to tip of snout); eye to nostril distance, E-N (distance between anterior-most point of eyes and nostrils);

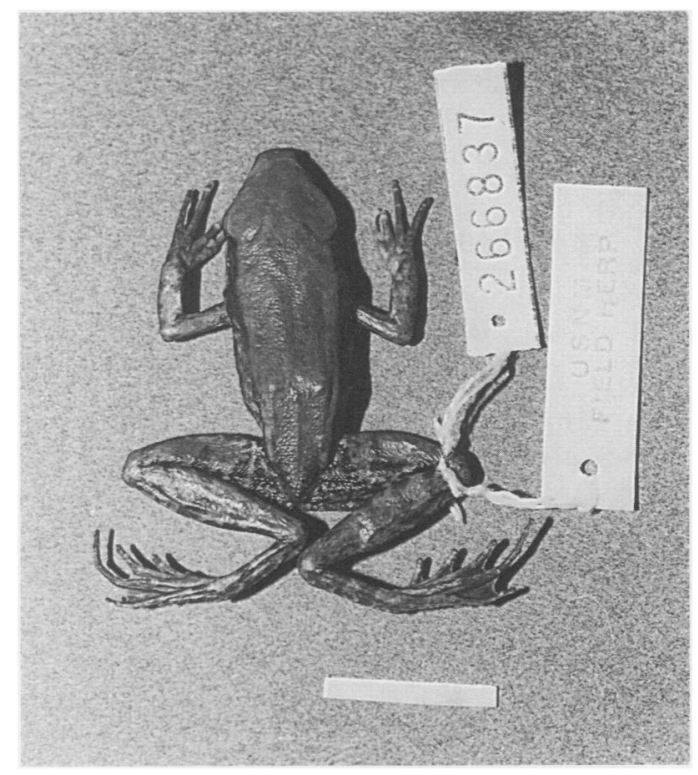

FIG. 1. Holotype of Rana chitwanensis sp. nov. (USNM 266837). Marker $=15 \mathrm{~mm}$.

greatest horizontal diameter of tympanum, HTYD (measured along horizontal plane); greatest vertical diameter of tympanum, VTYD (measured along vertical plane); and diameter of disk on finger III, FIID (width of disk at tip of finger II). Measurements of fingers and toes were taken from base of each phalange to tip, on right fore and hind limbs, respectively. Sex was determined through examination of gonads.

Institutional abbreviations follow Leviton et al. (1985). Sources of information on distribution of congenerics with which the new species have been compared are Boulenger (1920), Duellman (1993), and Frost (1985), supplemented with distributional information associated with comparative material examined (see Appendix I).

\section{Rana chitwanensis sp. nov.}

(Figs. 1-2)

Holotype.-USNM 266837 (adult female with developing eggs), from seven $\mathrm{km}$ SSE Kasara, Royal Chitwan National Park $\left(27^{\circ} 30^{\prime} \mathrm{N} ; 84^{\circ} 20^{\prime} \mathrm{E}\right)$, Nepal, 29 April, 1985. Collected by J. C. Mitchell.

Paratypes.-USNM 266838 and USNM 266839 (both juvenile males), from ca. six km S Sauraha, Royal Chitwan National Park $\left(27^{\circ} 30^{\prime} \mathrm{N}\right.$; $84^{\circ} 20^{\prime}$ E), Nepal, 1 November, 1985 . Collected by G. R. Zug.

Diagnosis.-Rana chitwanensis sp. nov. is diagnosable from congeners in possessing the following characteristics: head longer than wide; tympanum rounded, smaller than orbit diameter; supratympanic fold absent; finger I longer 